\title{
Conversas Difíceis em Medicina
}

\author{
Amaral, Anna Beatriz Costa Nevesdo; Silva, Carlos Henrique Martins; Canto, Paula \\ Philbert Lajolo \\ Universidade Federal de Uberlândia — beatriz_amaral@hotmail.com
}

Introdução Durante a prática médica, o ato de comunicar más notícias é comum e afeta médicos, pacientes e familiares. a adequada comunicação em saúde aumenta a empatia que o paciente tem por seu médico e melhora a adesão ao tratamento. Levantamento realizado no setor de pediatria desta instituição verificou que alunos, residentes e pediatras julgam as habilidades em comunicação muito importantes para sua profissão, porém sentem-se pouco confiantes para executá-las. um dos motivos relacionados foi falta de capacitação durante a graduação. Embora vários cursos de Medicina ainda adotem o modelo curricular flexneriano, o Conselho Nacional de Educação e a Câmara de Educação Superior instituíram em 2001 novas diretrizes curriculares centradas no estudante e no processo ensino-aprendizagem e que incorporam a reflexão, ética, relações humanas e valores morais necessários ao ensino médico. Objetivo Descrever a implantação do ensino das habilidades de comunicação em saúde, num curso de Medicina em transição entre o currículo tradicional e as formas ativas de aprendizado. Métodos nas aulas da disciplina de Cultura Médica, grupos de 20 alunos do nono período do curso de Medicina de uma universidade federal brasileira receberam capacitação para aprimoramento da comunicação em saúde. As atividades são desenvolvidas em 5 passos e iniciam-se com sensibilização para o tema, quando é dada aos alunos oportunidade de refletir, sob a ótica de um familiar de um paciente gravemente doente. a seguir, uma exposição teórica de 20 minutos elenca passos técnicos da comunicação. em seguida realiza-se a dramatização de um atendimento médico pautado na comunicação de uma má notícia, seguido por reflexão em grupo sobre a cena. por último, uma narrativa é lida e discutida para conclusão das metas daquele encontro. Resultados Durante as aulas os alunos mostraram-se motivados e participativos. na atividade de sensibilização vivenciaram como é receber notícia ruim sobre o estado de saúde de um ente querido. Neste momento as diversas reações frente a possibilidade de perda ou injúria grave são trabalhadas e compartilhadas. a exposição teórica pontuou tópicos importantes na prática da comunicação: expor fatos, acolher sentimentos e organizar as etapas do cuidado antes de finalizar a conversa. As dramatizações demonstram que, mesmo em um ambiente simulado, os alunos sentem-se ansiosos, despreparados e inexperientes para enfrentar conflitos em saúde. a narrativa final, onde outros médicos compartilham suas vivências cotidianas, aproxima o aluno de seus pares, que apontam dificuldades comuns para quem enfrenta situações semelhantes. Conclusões Apesar de ser um curso de curta duração, a capacitação dos alunos através do uso de simulações de situações clínicas, narrativas e reflexão sobre posturas éticas em situações graves está sendo positiva e de alta aplicabilidade na transição para as práticas clínicas de internato.

Amaral, Anna Beatriz Costa Nevesdo; Silva, Carlos Henrique Martins; Canto, Paula Philbert Lajolo. Conversas Difíceis em Medicina. In: Anais do Congresso Internacional de Humanidades \& Humanização em Saúde [= Blucher Medical Proceedings, num.2, vol.1]. São Paulo: Editora Blucher, 2014. ISSN 2357-7282 DOI 10.5151/medpro-cihhs-10409 